\title{
DEVELOPMENT OF THE NEW APPROACH TO QUALITY CONTROL OF EXTRACTS OF THE PLANT RAW MATERIAL ON THE EXAMPLE OF CONVALLARIA MAJALIS
}

\author{
V.A.Khanin, O.O.Moiseev, A.Ye.Babkina, O.M.Kotenko, A.G.Kotov \\ Pharmaceutical company "Zdorovye", Ltd. \\ Ivan Kozhedub Kharkiv University of Air Force \\ National University of Pharmacy \\ SE "Ukrainian Scientific Pharmacopeial Centre of Drug Quality"
}

Key words: HPLC-MS; identification; quantitative determination; multicomponent systems; medicinal plant raw material

\begin{abstract}
Currently, there is a significant amount of drugs created on the basis of the medicinal raw material of the natural origin at the pharmaceutical market of Ukraine. An important source of the medicinal plant raw material for manufacture of cardiotonic drugs is lily-of-the-valley (Convallaria Majalis). The extract of lily-of-the-valley contains a significant amount of cardiac glycosides; some of them are well studied and is widely used in pharmacy. To control the quality of the plant raw material specified the HPLC-MS method for identification and quantitative determination of the basic components of the lily-of-the-valley extract has been developed and validated. The new approach to identification and quantitative determination of the components of systems of the natural origin by chromatographic methods has been proposed; it allows tightening the requirements for quality of the medicinal raw material and fixing the quantitative composition of the raw material within a rather narrow range. Fixing the composition of the raw material will provide the achievement of the pharmacological effect envisaged by the developers of the drug. The application of the approach developed to the analysis of the medicinal raw material also helps to simplify and reduce the cost of pharmaceutical analysis.
\end{abstract}

To date, herbal medicines are a significant part of the pharmaceutical market. A peculiarity of these medicines is the inability to determine the extent of the pharmacological action of their individual components since often the therapeutic effect of herbal medicines is due to the combined effect of various biologically active substances contained in the plant raw material $[3,4]$.

Currently, almost all methods of identification and quantitative determination of medicinal substances require the presence of the reference standard (RS) of the mixture components; many of these components are often commercially unavailable. This problem is particularly acute while analysing the plant raw material since it always contains some substances that have not been identified and described in the literature. Therefore, neither manufacturers nor consumers have the possibility to control the composition and the quantitative content of the extract components, and it opens up many possibilities for drug adulteration. In reference with the above mentioned, there is a need to develop methods for quality control of extracts without using RS.

A vivid example of a synergistic therapeutic effect of the components can be observed when considering the drugs created on the basis of the lily-of-the-valley extract. According to the literature data [5] dried aerial parts of this plant contain $0.1 \%$ to $0.5 \%$ of cardiac glycosides (Fig. 1). The main glycosides of this group are: convallato- xin (from $4 \%$ to $40 \%$ ), convalloside (from $4 \%$ to $24 \%$ ), convallatoxol (from $10 \%$ to $20 \%$ ), desglucocheirotoxin (from 3\% to $15 \%$ ) and lokundjoside (from $1 \%$ to $25 \%$ ) [7].

This plant raw material is used for a long time, and on its basis a number of drugs has been developed [2], in particular, the drug "Corglycon" produced by the LLC "Pilot Plant of the State Scientific Centre of Drugs (DNCLZ)". However, currently there are no methods for quantitative determination of the individual components of the drug.

The aim of the present work was to develop approaches to quality control of the lily-of-the-valley extract in order to provide the proper quality of such drugs.

\section{Experimental Part}

Determinations were carried out on an Agilent 1100 device with a diode array detector and an Agilent 6420 Triple Quad LC/MS mass spectrometer.

To identify the components the sample of convallatoxin (Sigma-Aldrich, cat. No.C9140), as well as the standard samples of the known components of the extract (convallatoxol, desglucocheirotoxin, lokundjoside and convalloside) synthesized in SE "Ukrainian Scientific Pharmacopeial Centre of Drug Quality" were used.

Validation of the analytical method was carried out in accordance with the requirements of the State Pharmacopoeia of Ukraine (SPhU) [1] using a mixture of five known components of the lily-of-the-valley extract as model samples. 
Linearity, accuracy, precision and specificity of the method developed have been confirmed in the course of validation $[6,9]$.

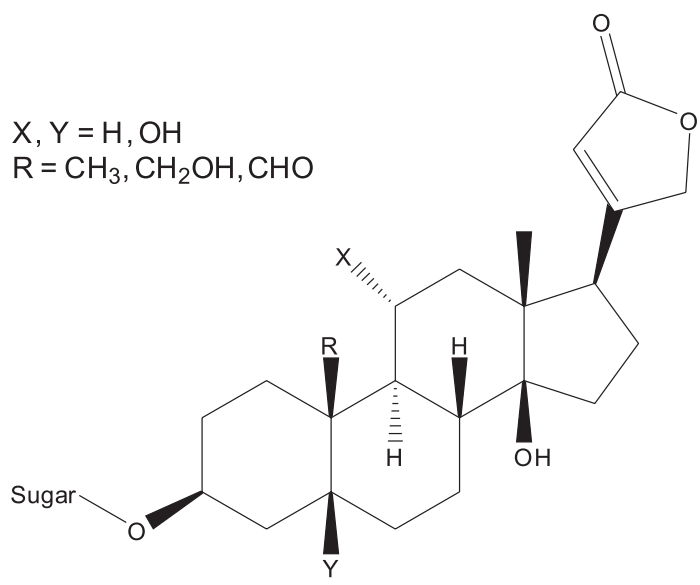

Fig. 1. The general formula of cardiac glycosides in lily-of-the-valley.

\section{Results and Discussion}

To solve this task the HPLC-MS method for identification and quantitative determination of the components of the lily-of-the-valley extract has been developed and validated.

The main idea of the approach developed is standardization of the components of the extract in relation to one identified component [8], and it is development of the classical idea of using an internal standard, which is widely used in analytical chemistry.

By the method developed the analysis of three samples of the lily-of-the-valley extract was conducted - the standardized sample of the lily-of-the-valley extract of 1982 year of manufacture and two samples of 2015 year of manufacture (Fig. 2, 3).

The analysis has confirmed the quality of extracts prepared in 2015 at the Pilot Plant of the DNCLZ. However, the difference in the quantitative composition of the extracts was found; it demanded standardization of the components calculated with reference to convallatoxin (as

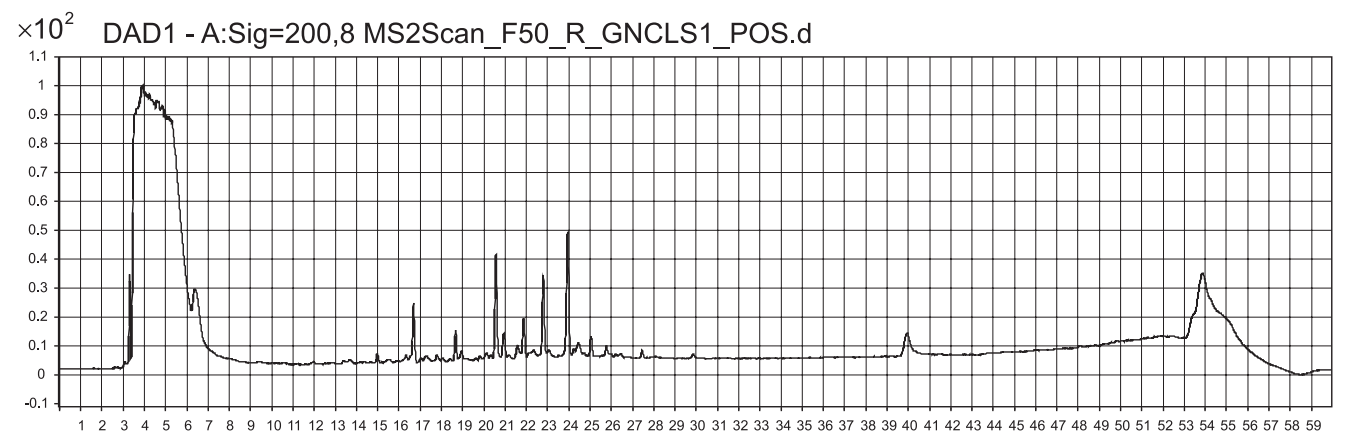

Response Units (\%) vs. Acquisition Time (min)

Fig. 2. The chromatogram of the standardized sample of the lily-of-the-valley extract.

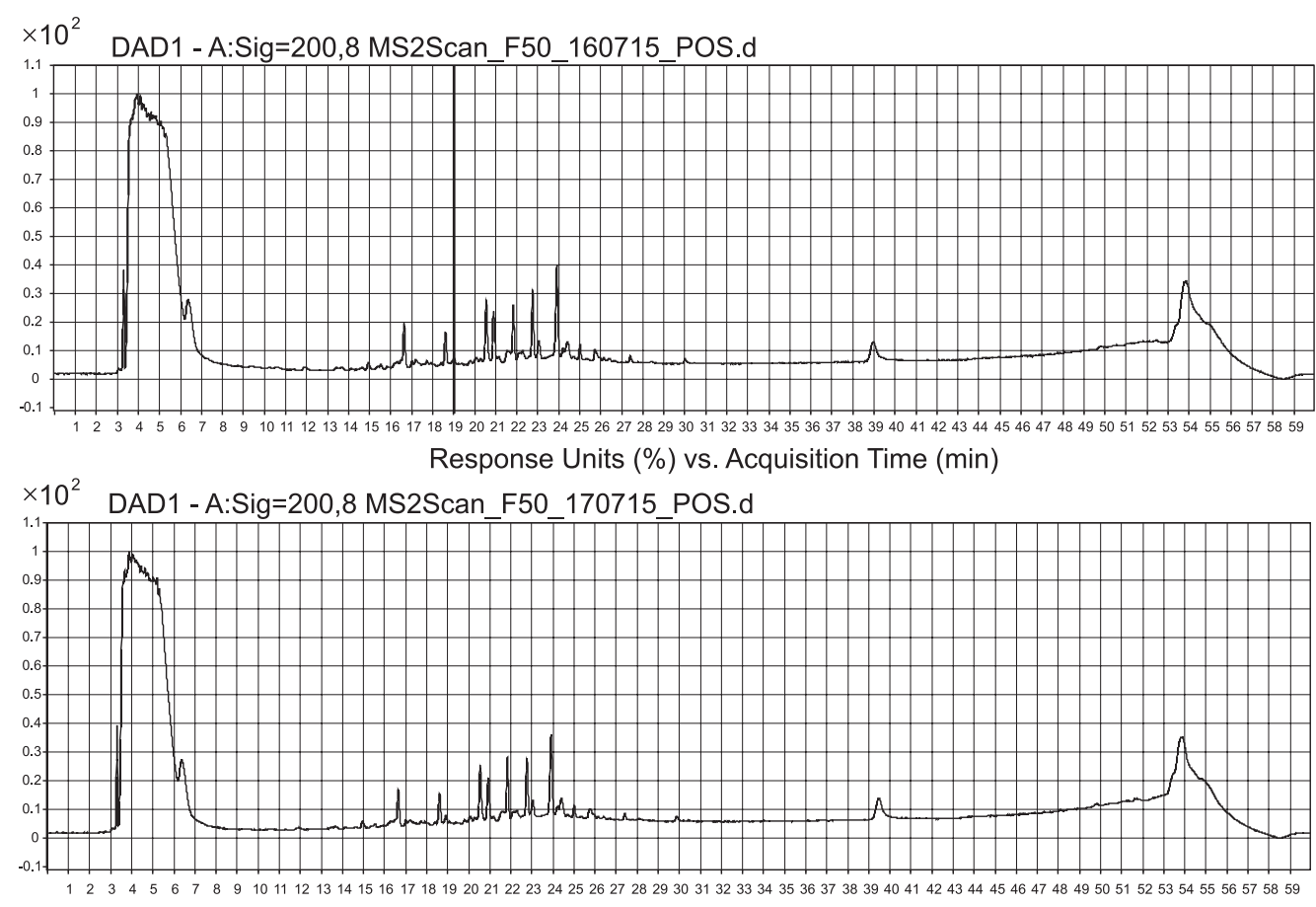

Response Units (\%) vs. Acquisition Time (min)

Fig. 3. The chromatograms of the samples of the lily-of-the-valley extract under research. 
a commercially available standard). The application of this approach allowed determining once (during validation of analytical method) the nominal ratio of peak areas and the relative retention time of the major components in relation to the reference one. Further a standard sample of only one substance of the whole mixture can be used to control the content of components in the medicinal raw material.

The difference between the extinction coefficients for various components in this case does not affect the results of the analysis since the ratio of peak areas, but not their absolute value, are used to determine the quality of the raw material, i.e. this difference is automatically taken into account when determining the nominal ratio from the chromatograms of the model solution.

\section{CONCLUSIONS}

The approaches to quality control of the plant raw material have been developed with calculation of the content of all known components of the raw material with reference to one standard sample.

The method for quantitative determination and identification of five basic components of the lily-of-the-valley extract has been developed using HPLC-MS; its validation has been carried out in accordance with the requirements of the SPhU.

The analysis has been conducted, and the quality of several series of the lily-of-the-valley extracts has been confirmed. It has allowed making a conclusion about the quality of the drugs.

\section{REFERENCES}

1. Державна фармакопея Украӥни: в 3-х m. / Державне підприємство «Украӥнський науковий фармакопейний иентр якості лікарських засобів». - 2-е вид. - Х.: Державне підприємство «Украйнський науковий фармакопейний ичентр якості лікарських засобів», 2015. - T. 1. - 1128 с.

2. Довідник лікарських засобів, зареєстрованих в Украӥні [Електронний ресурс]. - Режим доступу: httрs:// medhub.info/31246dcb

3. Литвиненко В.И., Попова Т.П., Дихтярев С.И. и др. // Фітотерапія. Часопис. - 2012. - №2. - С. 59-62.

4. Шостак Т.А., Калинюк Т.Г., Гудзь Н.I. // Фітотерапія. Часопис. - 2014. - №4. - C. 77-82.

5. Chushenko V.N., Vinnik E.V., Komissarenko N.F. et al. // Chem. Nat. Compd. - 1992. - Vol. 28. - P. $242-243$.

6. European Pharmacopoeia. - 8-th ed. - Strasbourg: European Directorate for the Quality of Medicines, Council of Europe, 2013. - 3655 p.

7. Kopp B., Kubelka W. // Planta Med. - 1982. - Vol. 45. - P. 195-202.

8. Moiseev O.O., Dorovskoi O.V., Khanin V.A. et al. // Bicнuк фармаuï̈. - 2013. - №4. - C. 19-22.

9. The United State Pharmacopeia: 37-NF32. - Rockville: The United State Pharmacopeia, Inc., 2014. - 3503 p.

РОЗРОБКА НОВОГО ПІДХОДУ ДО КОНТРОЛЮ ЯКОСТІ ЕКСТРАКТІВ РОСЛИННОї СИРОВИНИ НА ПРИКЛАДІ ЕКСТРАКТУ CONVALLARIA MAJALIS

В.А.Ханин, А.А.Моисеев, А.Е.Бабкина, О.М.Котенко, А.Г.Котов

Ключові слова: ВEPX-МС; ідентифікація; кількісне визначення; багатокомпонентні системи; лікарська рослинна сировина

На сьогодні на фрармацевтичному ринку України представлена значна кількість лікарських препаратів, створених на основі лікарської сировини рослинного походження. Важливим джерелом лікарської рослинної сировини для виробництва кардіотонічних засобів є конвалія травнева (Convallaria majalis). Екстракт конвалії травневої містить значну кількість серцевих глікозидів, частина яких добре вивчена та широко застосовується у фармації. Для контролю якості зазначеної рослинної сировини була розроблена та валідована ВЕРХ-МС-методика ідентифрікації та кількісного визначення основних компонентів екстракту конвалії травневої. Запропонований новий підхід до ідентифікації та кількісного визначення компонентів систем природного походження хроматографічними методами, які дозволяють ввести більш жорсткі вимоги до якості лікарської сировини та зафіксувати кількісний склад сировини в достатньо вузьких межах. Фіксація складу сировини дозволить забезпечити досягнення того фармакологічного ефекту, який планували розробники препарату. Також застосування розробленого підходу до аналізу лікарської сировини дозволить спростити та здешевити фрармацевтичний аналіз.

\section{РАЗРАБОТКА НОВОГО ПОДХОДА К КОНТРОЛЮ КАЧЕСТВА ЭКСТРАКТОВ РАСТИТЕЛЬНОГО СЫРЬЯ НА ПРИМЕРЕ ЭКСТРАКТА CONVALLARIA MAJALIS}

\section{В.А.Ханин, А.А.Моисеев, А.Е.Бабкина, А.М.Котенко, А.Г.Котов}

Ключевые слова: ВЭЖХ-МС; идентификация; количественное определение; многокомпонентные системы; лекарственное растительное сырье В настоящее время на фрармацевтическом рынке Украины представлено значительное количество лекарственных препаратов, созданных на основе лекарственного сырья растительного происхождения. Важным источником лекарственного растительного сырья для производства кардиотонических средств является ландыш майский (Convallaria Majalis). 
Экстракт ландыша майского содержит значительное количество сердечных гликозидов, часть которых хорошо изучена и широко применяется в фрармации. Для контроля качества указанного растительного сырья была разработана и валидирована ВЭЖХ-МС-методика идентифрикации количественного определения основных компонентов экстракта ландыша майского. Предложен новый метод идентификации и количественного определения компонентов систем природного происхождения путем хроматографрических исследований, позволяющих ужесточить требования к качеству лекарственного сырья и зафиксировать количественный состав сырья в достаточно узких пределах. Фиксация состава сырья позволит обеспечить достижение того фрармакологического эффректа, который закладывали разработчики препарата. Также применение разработанного подхода к анализу лекарственного сырья позволяет значительно упростить и удешевить проведение фрармацевтического анализа. 